\title{
S5ynthesis
}

International Scientific Conference of IT and Business-Related Research

\section{BUSINESS ENGLISH VERSUS GENERAL ENGLISH: STUDENTS' ATTITUDES AND GRADES}

\section{RAZLIKE IZMEĐU POSLOVNOG ENGLESKOG I OPŠTEG ENGLESKOG JEZIKA: STAVOVI I OCENE STUDENATA}

\author{
Valentina Bošković, Ivana Tomić, Nataša Stanišić, Slavko Alčaković \\ Singidunum University, Faculty of Business, 32 Danijelova St., Belgrade, Serbia
}

\begin{abstract}
:
The purpose of this paper is to analyze the success of students depending on the type of English they learn- whether it is business English or general English. The paper highlights the main differences between acquiring general English and business English. The theoretical overview of ESP and general English in the classroom is provided, along with syllabi for the English language courses at Singidunum University. Having in mind that students at Singidunum University learn general English for the first two years and business English in the $3^{\text {rd }}$ and $4^{\text {th }}$ year of studies, the authors of this paper conducted research which presents students' attitudes towards learning English and gives an answer to the question concerning the type of English that is easier to learn. Furthermore, the paper includes statistical data about students' grades in English courses throughout all four years of undergraduate academic studies.
\end{abstract}

\section{Key words:}

ESP, general English, business English.

\section{INTRODUCTION}

Since the advent of globalization, the necessity for business English has constantly been on the increase. In the era of global business ventures, business English is not only the crucial English language skill every employee is expected to have, but it is also an essential display of an employee's education, performance and overall competence. Furthermore, many English language schools offer courses in business English. Therefore, business English should be highlighted as the key subject at the universities that offer business studies. This is why the Faculty of Business at Singidunum University has introduced the course in business English in the $3^{\text {rd }}$ and $4^{\text {th }}$ year of undergraduate academic studies, having in mind that all students should be able to speak (business) English fluently.

The purpose of this paper is to show students' attitudes towards general English and business English and to examine whether their results are affected by the type of English course they take. The paper offers the theoretical overview of the main differences between acquiring general English and business English, as well as the general students' attitudes regarding this issue. Even though the role of a teacher is also relevant, this paper shall specifically analyze the role and attitudes of students.

\section{Apstrakt:}

Cilj ovog rada jeste da se analizira uspeh studenata u zavisnosti od toga da li uče poslovni engleski ili opšti engleski jezik. U radu se ističu osnovne razlike u usvajanju opšteg i poslovnog engleskog jezika, kao i najčešće prepreke sa kojima se studenti susreću prilikom učenja. Rad daje kratak teorijski uvod u engleski kao jezik struke i opšti engleski u učionici, uz predstavljene silabuse na Univerzitetu Singidunum. Imajući u vidu da student na Univerzitetu Singidunum uče opšti engleski na prve dve godine studija, a poslovni engleski na trećoj i četvrtoj godini osnovnih akademskih studija, autori ovog rada su sproveli istraživanje u kom se analiziraju stavovi studenata prema učenju engleskog jezika i koje daje odgovor na pitanje da li je lakše učiti opšti ili poslovni engleski jezik. Rad takođe prikazuje statističke podatke o ocenama studenata iz predmeta Engleski jezik tokom sve četiri godine osnovnih akademskih studija.

\section{Ključne reči:}

ESP, opšti engleski, poslovni engleski

Besides the theoretical overview, the paper introduces syllabi for the English language courses at Singidunum University. It also includes the research which presents students' attitudes about learning English and gives an answer to the question concerning the type of English that is easier for students to learn. Statistical data on students' grades in English courses throughout all four years of undergraduate academic studies are presented as well.

\section{English for Specific Purposes versus General English}

In the process of teaching English for specific purposes (ESP), an emphasis is placed on meeting the specific needs of the learners. It is usually considered a separate activity within English Language Teaching (Dudley-Evans, St John, 1998:1). Unlike general English teaching (also referred to as ESL - English as a Second Language), ESP focuses on vocabulary and communication, while strict grammar rules are usually ignored. The guiding principle of ESP is "Tell me what you need English for and I will tell you the English that you need" (Hutchinson, Waters, 1987:8). Business English, which is considered a part of this concept, is probably the broadest variety of ESP, mostly due to its numerous teaching purposes (Jonson, 1993:201). Business 
English may refer to communication skills that are necessary in the workplace, or language skills typical for business communication, such as presentations, meetings, negotiations, job interviews, CV writing, report writing, correspondence, finance, internal relations, etc.

In specific teaching situations, ESP uses different methods from those used in general language teaching. In most cases, ESP is taught to adults, who already have some basic knowledge of English. When they start learning ESP, candidates are usually at intermediate or advanced level (Anthony, 1997).

As previously mentioned, the most important difference between ESP and ESL is the purpose of learning the language. Learners have different goals at various stages of learning English. ESL focuses on grammar and language structure, which means that all four language skills are equally important. In ESP, the focus is on vocabulary, content and topics. Language skills are taught according to the learners' needs. The emphasis is most often on reading, listening and communication skills (Fiorito, 2005).

ESP is a combination of certain subject matter and English language teaching (Fiorito, 2005). As regards Business English, it is a combination of the English language and the following areas: finance and banking, marketing and trade, business communication in general, etc. The fact that students have the opportunity to apply the acquired knowledge of English to their main field of interest is very motivating. Additionally, their technical knowledge in the given field facilitates English language learning (Fiorito, 2005).

As regards materials for ESP courses, regular textbooks are usually not sufficient enough. Teachers who teach ESP must have the plan for the course, as well as provide additional materials for it (Dudley-Evans, St John, 1998:14). Teaching ESP requires special skills and considerable effort. Most of ESP teachers' work is about designing the appropriate courses for different groups of learners, while courses in general English are usually determined by the choice of textbook (Hutchinson, Waters, 1987:21).

\section{English study programme at business studies}

The students at the Faculty of Business at Singidunum University learn general English in the first two years of studies and business English in the third and fourth year of studies.

English Language 1 and English language 2 are the courses which last two semesters and are based on the textbook Complete First Certificate (Cambridge University Press), which corresponds to upper-intermediate level or Common European Framework level B2.

English Language 3 and English Language 4 are the courses which also last two semesters. Both are based on the textbook Business Benchmark (Cambridge University Press), which corresponds to the advanced level or Common European Framework level C1. Apart from compulsory textbooks, different supplementary material is provided, including the following textbooks: English for Business Studies (CUP), BEC Higher (Summertown Publishing) and Professional English in Use Finance 1st Edition.

English Language 3 is based on the acquisition of business vocabulary, understanding the principles of business and conducting basic business communication. Teaching units enable students to improve their business vocabulary and use it in conversation, with special skills of negotiation and business correspondence.

English Language 4 is based on the acquisition, understanding and usage of terminology in the area of economics, market- ing, trade, accounting and auditing. The acquired knowledge is also used in written and oral communication, case studies, debates, writing of business letters and essays.

\section{RESEARCH - METHODOLOGY AND RESULTS}

The aim of the paper is to examine students' attitudes regarding the ways they acquire business English and general English, as well as its importance for English language learning in general. The hypotheses which are the basis of the research are the following:

H1: The students at Singidunum University find business English harder to learn than general English.

H2: The students at Singidunum University find the knowledge of business English crucial for the English language learning in general.

$\mathrm{H} 3$ : Regarding the higher level (C1) and specific purpose of language (ESP) students learn in the $3^{\text {rd }}$ and $4^{\text {th }}$ year of studies, it is expected that students' GPA will be lower compared to their GPA in the first two academic years.

The research presented in this paper includes 120 respondents who are students at Singidunum University in the $3^{\text {rd }}$ and $4^{\text {th }}$ year of undergraduate academic studies, as those students are competent to judge which type of English (general or business) is harder to learn. The research includes an anonymous questionnaire which consists of 15 questions regarding students' opinion about general English and business English. The research results are analyzed in SPSS 21 (Statistical Package for Social Sciences, version 21), and show students' attitudes towards learning English for specific purposes and general English.

The overall number of respondents includes 84 female students (70\%) and 36 male students (30\%). As regards the age of respondents, $36.7 \%$ is at the age of 23 , the same percentage refers to those aged 22, while $9.2 \%$ of respondents is 24 years old. While $8.3 \%$ of respondents is at the age of $26,5.8 \%$ of students is 25 , and $3.3 \%$ is 21 years old.

As regards the departments the students study at, the highest percentage attends Finance and Banking (42 respondents - 35\%), Accounting and Auditing (36 respondents - 30\%), Business Economics (27 respondents - 22. 5\%) and Marketing and Trade (15 respondents $-12.5 \%$ ).

The results show that students find business English harder to learn $(83.3 \%)$ than general English (3.3\%). Moreover, they also think that it is more difficult to study for the English exams in the $3^{\text {rd }}$ and $4^{\text {th }}$ year of studies $(71.7 \%)$ than in the $1^{\text {st }}$ and $2^{\text {nd }}$ year (17.5\%), as presented in Tables 1 and 2 .

Business English vocabulary is harder to learn than general English.

\begin{tabular}{|l|c|c|}
\hline & Respondents & Percent \\
\hline I completely disagree & 1 & 0.8 \\
\hline I mainly disagree & 3 & 2.5 \\
\hline I am not sure & 4 & 3.3 \\
\hline I mainly agree & 34 & 28.3 \\
\hline I completely agree & 78 & 65 \\
\hline \multicolumn{1}{|c|}{ Total } & 120 & 100 \\
\hline
\end{tabular}

Table 1. Business English vocabulary versus general English 
It is harder to pass English Language 3 and 4 than English language 1 and 2

\begin{tabular}{|l|c|c|}
\hline & Respondents & Percent \\
\hline I completely disagree & 8 & 6.7 \\
\hline I mainly disagree & 13 & 10.8 \\
\hline I am not sure & 13 & 10.8 \\
\hline I mainly agree & 24 & 20 \\
\hline I completely agree & 62 & 51.7 \\
\hline \multicolumn{1}{|c|}{ Total } & 120 & 100 \\
\hline
\end{tabular}

Table 2. It is harder to pass English Language 3 and 4 than English language 1 and 2

However, when it comes to students' attitudes regarding the importance of business English in the acquisition of the English language, the results presented in Table 3 show that students do not find business English as a crucial means for learning English.

In order to acquire English, I have to know business vocabulary

\begin{tabular}{|l|c|c|}
\hline & Respondents & Percent \\
\hline I completely disagree & 13 & 10.8 \\
\hline I mainly disagree & 43 & 35.8 \\
\hline I am not sure & 21 & 17.5 \\
\hline I mainly agree & 24 & 20 \\
\hline I completely agree & 19 & 15.8 \\
\hline \multicolumn{1}{|c|}{ Total } & 120 & 100 \\
\hline
\end{tabular}

Table 3. In order to acquire English, I have to know business vocabulary

On the other hand, most respondents are not aware of the importance of business English. According to the research results, $32.5 \%$ of students are not sure whether they should learn more business English than general English in classes.

We should learn more business English than general English in classes

\begin{tabular}{|l|c|c|}
\hline & Frequency & Percent \\
\hline I completely disagree & 13 & 10.8 \\
\hline I mainly disagree & 21 & 17.5 \\
\hline I am not sure & 39 & 32.5 \\
\hline I mainly agree & 26 & 21.7 \\
\hline I completely agree & 21 & 17.5 \\
\hline \multicolumn{1}{|c|}{ Total } & 120 & 100 \\
\hline
\end{tabular}

Table 4. We should learn more business English than general English in classes.

\section{Students' Grades}

According to data taken from university information system, students' GPA (grade point average) at each year regarding the courses English Language 1, 2, 3 and 4 shows that there is no huge discrepancy between students' achievements when studying General English or Business English. As regards the results shown in Table 5 , the third hypothesis has been proved wrong since there is no expected discrepancy between students' GPA in the first two years and the final years of their studies. The following table clearly depicts students' GPA in several academic years.

\begin{tabular}{|l|c|c|c|c|c|c|}
\hline & 2008 & 2009 & 2010 & 2011 & 2012 & 2013 \\
\hline English Language 1 & 7,81 & 7,59 & 8,01 & 8,02 & 8,22 & 7,87 \\
\hline English Language 2 & 7,68 & 7,95 & 7,88 & 7,87 & 8,27 & \\
\hline English Language 3 & 7,55 & 8,11 & 7,87 & 7,96 & & \\
\hline English Language 4 & 7,69 & 7,71 & 7,76 & & & \\
\hline
\end{tabular}

Table 5. Students' Grades

\section{SUMMARY}

Even though students claim that there is a discrepancy between their ability to acquire business English and general English, the data obtained from the university information system clearly depict that this discrepancy is irrelevant. On the other hand, the research results show that students find business English language acquisition more difficult than general English language learning. The second hypothesis has been proved wrong since the research results show that students do not seem to understand the importance and necessity of business English when it comes to the acquisition of the English language in general. Therefore, English language teachers should motivate students to learn ESP, thus preparing them for future business demands of the workplace.

The recommendation for similar research in the future is to take into consideration students' previous knowledge of the English language, having in mind that not all students enroll at the university with the same level of English language skills. Additional research regarding teachers' role in classroom should be conducted to find out the ways in which they create and adapt their lectures to students' needs at higher level of language learning.

\section{REFERENCES}

Jonson, C. (1993). LTS Training and Consulting. Cambridge Journals, 26(4), 201-209.

Hutchinson, T., \& Waters, A. (1987). English for specific purposes: A learning-centred approach. Cambridge: Cambridge University Press.

Dudley-Evans, T., \& St John, M. (1998). Developments in English for Specific Purposes: A Multidisciplinary Approach. Cambridge, UK: Cambridge University Press.

Anthony, L. English for Specific Purposes: What does it mean? Why is it different. Retrieved on $1^{\text {st }}$ March 2015 from: http:// www.laurenceanthony.net/abstracts/ESParticle.html

Fiorito, L. (2005). Teaching English for Specific Purposes. Retrieved on $1^{\text {st }}$ March 2015, from http://www.usingenglish. com/articles/teaching-english-for-specific-purposes-esp. html

Brook-Hart, G. (2007). Business Benchmark Advanced Higher. Cambridge, UK: Cambridge University Press.

MacKenzie, I. (2010). English for Business Studies.Cambridge, UK: Cambridge University Press.

Brook-Hart, G. (2014). Complete First Certificate. Cambridge, UK: Cambridge University Press.

MacKenzie, I. (2006). Professional English in Use Finance. Cambridge, UK: Cambridge University Press.

Wood, I., Pile, L., \& Curtis, S. (2012). PASS Cambridge BEC Higher. UK: Summertown Publishing. 


\section{APPENDIX:}

\section{UPITNIK}

Molimo Vas da popunite upitnik koji će se koristiti za istraživanje u naučno-istraživačkom radu na temu „Business English versus General English: an Example of English Studies at Singidunum University“. Rezultati će biti predstavljeni na konferenciji Sinteza na Univerzitetu Singidunum. Upitnik je anoniman.

Uputstva za popunjavanje upitnika:

Pred Vama se nalazi upitnik koji se sastoji od 15 stavki. Molimo Vas da odgovorite u kom stepenu se slažete sa svakom od njih tako što ćete zaokružiti odgovarajući broj:

1 - u potpunosti se ne slažem

2 - uglavnom se ne slažem

3 - nisam siguran/na

4 - uglavnom se slažem

5 - u potpunosti se slažem

Molimo Vas da iskreno odgovorite na sva pitanja!

\section{PITANJA}

Pol: $\quad M \quad \check{Z}$

Godište:

Fakultet:

Smer:

1. Gramatika engleskog jezika je laka za učenje.

2. Da bih mogao/mogla da savladam engleski jezik, moram da znam gramatiku.

3. Bez gramatike engleskog jezika ne umem da koristim engleski.

4. Gramatika engleskog jezika je nepotrebna za usvajanje jezika.

5. Treba više raditi na poslovnom vokabularu nego na gramatici engleskog jezika.

6. Poslovni vokabular na engleskom jeziku je teži od gramatike.

7. Otkad učim poslovni engleski, lakše se sporazumevam sa strancima.

8. Da bih mogao/mogla da savladam engleski jezik, moram da znam poslovni vokabular.

9. Treba da učimo više poslovnog vokabulara na predavanjima.

10. Moja ocena iz predmeta Engleski jezik zavisi od toga da li se više uči gramatika ili poslovni vokabular.

11. Moja motivacija za učenje engleskog jezika zavisi od toga da li se više uči gramatika ili poslovni vokabular.

12. Teže mi je da spremim ispit iz predmeta Engleski jezik na III i IV godini.

13. Smatram da imam odlično znanje gramatike engleskog jezika.

14. Smatram da imam odlično znanje poslovnog vokabulara na engleskom jeziku.

15. Van fakulteta bih pre učio/ učila gramatiku nego poslovni vokabular na engleskom. $\begin{array}{lllll}1 & 2 & 3 & 4 & 5\end{array}$

$\begin{array}{lllll}1 & 2 & 3 & 4 & 5\end{array}$

$\begin{array}{lllll}1 & 2 & 3 & 4 & 5\end{array}$

$\begin{array}{lllll}1 & 2 & 3 & 4 & 5\end{array}$

$\begin{array}{lllll}1 & 2 & 3 & 4 & 5\end{array}$

$\begin{array}{lllll}1 & 2 & 3 & 4 & 5\end{array}$

$\begin{array}{lllll}1 & 2 & 3 & 4 & 5\end{array}$

$\begin{array}{lllll}1 & 2 & 3 & 4 & 5\end{array}$

$\begin{array}{lllll}1 & 2 & 3 & 4 & 5\end{array}$

$\begin{array}{lllll}1 & 2 & 3 & 4 & 5\end{array}$

$\begin{array}{lllll}1 & 2 & 3 & 4 & 5\end{array}$

$\begin{array}{lllll}1 & 2 & 3 & 4 & 5\end{array}$

$\begin{array}{lllll}1 & 2 & 3 & 4 & 5\end{array}$

$\begin{array}{lllll}1 & 2 & 3 & 4 & 5\end{array}$

$\begin{array}{lllll}1 & 2 & 3 & 4 & 5\end{array}$

HVALA! 